\title{
Polityka regionalna jako podstawa rozwoju przemysłu motoryzacyjnego w województwie śląskim
}

\section{Regional policy as the basis for the development of the automotive industry in the Silesian voivodeship}

\author{
Krzysztof Toboła*
}

\begin{abstract}
Abstrakt
Przemysł motoryzacyjny w województwie śląskim zyskuje na znaczeniu. Wpływ na to ma wiele czynników, spośród których działania polityczne władz samorządowych województwa śląskiego wraz z administracją rządową należą do jednych ważniejszych. Elementem działań politycznych był m.in. „Kontrakt regionalny dla województwa katowickiego" oraz Strategia Rozwoju Województwa Śląskiego. W wyniku tej aktywności powstała Katowicka Specjalna Strefa Ekonomiczna, co wyraźnie rzutowało i nadal rzutuje zarówno na powstawanie nowych, jak i rozbudowę już istniejących zakładów związanych z branżą motoryzacyjną. Są to m.in. Fiat Auto Poland, Opel, Isuzu, Magneti Marelli. Rozwój tej gałęzi przemysłu staje się dużą szansą na skok technologiczny oraz restrukturyza-
\end{abstract}

\begin{abstract}
The automotive industry in Silesia province is becoming more important. It is influenced by many factors among which one of the most important are political activities of the self-government authorities in Silesia province together with government administration. For example, the element of political activities was "The regional contract for the Katowice province" and Silesian Region Development Strategy. As the result of this activity, the Katowice Special Economic Zone was established, what was clearly affected and continues to affect the creation of new ones and the expansion of existing plants related to the automotive industry. For example, they are Fiat Auto Poland, Opel, Isuzu, Magneti Marelli. The development of this branch of industry is a great opportunity for a big technological
\end{abstract}

* doktorant (tobola.service@gmail.com); ORCID: 0000-0003-3221-1243. 
cję gospodarki dla województwa śląskiego i dla Polski.

Słowa kluczowe: działania polityczne, Górny Śląsk, Katowicka Specjalna Strefa Ekonomiczna, Kontrakt regionalny dla województwa katowickiego, Kontrakt Wojewódzki dla Województwa Śląskiego, region, rozwój przemysłu motoryzacyjnego, Strategia Rozwoju Województwa Śląskiego, Śląskie, Wojewódzki Program Operacyjny Województwa Śląskiego, województwo leap and restructuring of the economy for Silesia province and for Poland.

Key words: public policy, Upper Silesia, Katowice Special Economic Zone, Regional contract for the Katowice province, Provincial Contract for the Silesian Province, region, development of the automotive industry, Silesian Region Development Strategy, Silesian, Regional Operational Programme of Silesia, province

Dynamicznemu rozwojowi, a co za tym idzie — zwiększeniu znaczenia kraju na świecie, sprzyja przemyślana oraz dobrze dopasowana polityka władz państwa. Nieodzowna w takiej sytuacji jest odpowiednia polityka regionalna, która stanowi część polityki ekonomicznej i wynika bezpośrednio z regionalizacji ekonomicznej kraju. Z uwagi na to, że każdy region ma swoją specyfikę, polityka regionalna powinna być dopasowana do tej specyfiki. Jak wyjaśnia Antoni Jarosz w pracy zbiorowej: „Polityka regionalna dotyczy: funkcji, roli i miejsca danego regionu w całej gospodarce narodowej, kierunków specjalizacji rozwoju regio$\mathrm{nu}$, ustalenia programu aktywizacji regionów słabiej rozwiniętych i zmniejszania istniejących dysproporcji w ich zagospodarowaniu, skonkretyzowania powiązań międzyregionalnych i ustalenia współpracy regionów. Cele polityki regionalnej wiążą się więc z racjonalizowaniem procesu wzrostu gospodarczego i rozwoju społecznego oraz procesu produkcji i podziału w ujęciu przestrzennym [...]”'.

Oprócz odpowiedniej polityki regionalnej o statusie państwa decyduje również to, czy jego gospodarka jest dynamicznie rozwijająca się, chłonąca nowoczesne technologie, co najczęściej wynika z dobrze skoordynowanego zaplecza naukowo-technicznego i swobodnej współpracy na arenie międzynarodowej, a także to, czy na obszarze danego kraju panuje sprzyjający klimat polityczny dla szeroko pojętej przedsiębiorczości. Najczęściej spotykanym przykładem nowoczesnej gospodarki jest gospodarka rynkowa, gdzie podmioty takie, jak przedsiębiorstwa, instytucje finansowe, gospodarstwa domowe, gospodarstwa rolne oraz rządy poszczególnych państw, prowadzą ją w ten sposób, że kierują się własnym interesem i postępują zgodnie z zasadami racjonalnego gospodarowania. W Polsce po przemianach ustrojowych 1989 roku przeważa właśnie gospodarka rynkowa.

Znaczący rozwój technologiczny, a co za tym idzie - modernizacja i rozbudowa przemysłu mają w gospodarce każdego państwa szczególne znaczenie

\footnotetext{
${ }^{1}$ A. Jarosz, K. LeŚniak-Moczuk: Polityka regionalna. Rzeszów 1998, s. 11-25.
} 
dla poprawy kondycji ekonomicznej kraju, a także dla wzmocnienia znaczenia danego kraju na arenie międzynarodowej. Spośród wielu gałęzi przemysłu sektor motoryzacyjny należy do najbardziej znaczących pod kątem zarówno nowoczesności, jak i perspektywiczności w gospodarce światowej. Od 1945 roku, czyli po II wojnie światowej, a w dalszej kolejności po przeobrażeniach demokratycznych, w Polsce wiele zakładów związanych z przemysłem motoryzacyjnym, takich jak Fabryka Samochodów Małolitrażowych (później Fiat Auto Poland) wraz z liczną grupą kooperantów, fabryka Opla czy też zakład Isuzu, ulokowano na obszarze dzisiejszego województwa śląskiego. Autor publikacji Dzieje polskiej motoryzacji, Stanisław Szelichowski, wyraźnie stwierdza w tym kontekście, że dwa miasta leżące w województwie śląskim, czyli Bielsko-Biała oraz Tychy, wykorzystały swoją szansę w kwestii produkcji samochodów i podzespołów do ich produkcji². Należy tu powiedzieć, że od 1950 roku do końca 1998 roku, podczas kolejnych podziałów administracyjnych spora część dzisiejszego województwa śląskiego nosiła nazwę województwa katowickiego. Znacząca część dzisiejszego województwa śląskiego, jak i wcześniejszego województwa katowickiego jest utożsamiana $\mathrm{z}$ regionem historycznym nazywanym Górnym Śląskiem. Region ten zarówno wcześniej, jak i teraz poprzez wyjątkowo dobre położenie geograficzne, rozbudowaną infrastrukturę drogową i techniczną, zaplecze naukowe, dostępność surowców naturalnych, znaczne uprzemysłowienie oraz duże skupisko ludzkie rozwija się dynamicznie i dlatego w sposób naturalny staje się miejscem lokalizacji nowych przedsiębiorstw. Tym bardziej oczywisty staje się fakt, że dotyczy to także branży związanej z przemysłem motoryzacyjnym. $Z$ upływem czasu zaczęto nazywać ten region zagłębiem motoryzacyjnym.

Jak wynika z raportu końcowego z 2013 roku powstałego na zlecenie Urzędu Marszałkowskiego województwa śląskiego pod tytułem: Analiza potencjału rozwojowego funkcji metropolitarnych obszarów aglomeracji miejskich będących ośrodkami wzrostu gospodarczego województwa ślaskiego w kontekście procesów zachodzących na regionalnym rynku pracy, województwo śląskie utrzymuje swoją wysoką, drugą, lokatę w skali całego kraju, ze względu na liczbę przedsiębiorstw i ich udział $\mathrm{w}$ sektorze usług nowoczesnych. Nie może więc dziwić fakt, że w takim właśnie środowisku lokalizuje swój przemysł branża samochodowa.

Na konferencji motoryzacyjnej „Transfer Wiedzy w Branży Motoryzacji: Nowe wyzwania - nowe inwestycje - nowe perspektywy współpracy" w listopadzie 2011 roku dyrektor Tadeusz Adamski powiedział: „Województwo Śląskie jest regionem, w którym przemysł motoryzacyjny odgrywa znaczącą rolę w gospodarce. Suma ok. 44 tys. pracowników tej branży, w stosunku do ok. 150 tys. w całej Polsce, oznacza to, że w regionie lokalizacja dużych zakła-

\footnotetext{
${ }^{2}$ S. Szelichowski: Dzieje polskiej motoryzacji. Łódź 2012, s. 98-105.
} 
dów wytworzyła taką sytuację, która w województwie przyczyniła się do powstania silnego zaplecza dostawców z sektora MŚP, wytwarzających produkty dla przemysłu motoryzacyjnego. $\mathrm{W}$ regionie umiejscowiono również znaczną ilość jednostek badawczo-rozwojowych i uczelni wyższych, których potencjał jest i może jeszcze bardziej być wykorzystany przy realizacji wspólnych przedsięwzięć gospodarczych"’. Na potwierdzenie tej opinii powinno się tu wymienić niektóre lokalizacje zakładów motoryzacyjnych. Przede wszystkim fabrykę samochodów marki Fiat w Tychach i Bielsku-Białej, która wcześniej nazywała się Fabryką Samochodów Małolitrażowych (FSM), oraz nowo wybudowany przez General Motors w Gliwicach zakład produkcyjny samochodów marki Opel. Ponadto zlokalizowano na obszarze województwa śląskiego wiele innych zakładów, które dostarczają podzespoły samochodowe do fabryk produkujących samochody w tym i innych regionach Polski, a nawet świata. Do grupy tych przedsiębiorstw należą między innymi niemieckie firmy Mahle i HP-Pelzer, amerykańskie TRW i Delphi, japoński Isuzu oraz włoskie współpracujące z Fiatem - Magneti Marelli, Manuli Rubber oraz Teksid. Większa część tych producentów wybrała tereny należące do Katowickiej Specjalnej Strefy Ekonomicznej. W ramach tej głównej strefy przede wszystkim wybrane zostały przez różnych producentów podstrefy tyska i gliwicka.

Jak wynika z danych Polskiej Agencji Inwestycji, wielkie zagraniczne koncerny związane z branżą motoryzacyjną zainwestowały w tym rejonie Polski ok. 4 mld USD. Podstawą do takiej decyzji, dotyczącej lokalizacji fabryk, były głównie czynniki wcześniej wymienione. Nie może więc dziwić fakt intensywnej obserwacji — przez inwestorów, badaczy i polityków — województwa śląskiego, a nawet całego Makroregionu Południowego, obejmującego swym zasięgiem województwa: śląskie i opolskie, gdyż zdecydowanie mają one dostatecznie dużą wagę w polskiej gospodarce ${ }^{4}$. Znaczna też część autorów współczesnych opracowań wykazuje, że panuje duże zainteresowanie lokalizowaniem przedsięwzięć z branży motoryzacyjnej na obszarach takich, jak Polska, Czechy, Słowacja czy też Węgry. Zauważyć jednak należy, że macierzyste zakłady tych inwestorów wywodzą się najczęściej z państw o znacznie wyższym poziomie rozwoju gospodarczego. Właściciele nowoczesnych przedsiębiorstw dysponujący znacznym kapitałem i nowymi technologiami, nastawieni na dynamiczny rozwój, bardzo często poszukują nowych lokalizacji dla swych inwestycji. Może ich zachęcić do zainwestowania $\mathrm{w}$ danym regionie wiele czynników, między innymi: dobre położenie, wykwalifikowani pracownicy, optymalne warunki finansowe oraz perspektywiczny rynek zbytu na ich produkty.

${ }^{3}$ Cyt. za: Ślaskie - nowoczesny przemyst motoryzacyjny - http://www.slaskie.pl/ strona_n.php?jezyk=pl\&grupa $=10 \& a r t=5122($ dostęp: 7.01 .2014$)$.

4 J. Siemianowicz: Czynniki produkcji przemystowej i eksport makroregionu poludniowego w procesie transformacji gospodarki. Kraków-Katowice-Zabrze 2001, s. 7—9. 
Ważnym elementem w przeprowadzanej analizie jest zaznaczenie istotnego faktu, iż tworzące się zakłady motoryzacyjne oddziaływają na cały region, co najczęściej sprzyja powstawaniu kolejnych zakładów kooperujących, a co za tym idzie - zwiększaniu zatrudnienia, tak jak już zresztą zostało wspomniane wcześniej ${ }^{5}$.

Przemiany społeczno-ustrojowe, jakie miały miejsce w 1989 roku, takie jak: obrady Okrągłego Stołu, częściowo wolne wybory parlamentarne, które odbyły się 4 i 18 czerwca, powołanie rządu Tadeusza Mazowieckiego w dniu 12 września oraz plan Balcerowicza, a następnie reforma samorządowa z 1990 roku włącznie z kolejnymi zmianami z jednej strony spowodowały zagrożenia dla rozwoju województwa katowickiego (później śląskiego), a z drugiej — stały się szansą na jego modernizację i szybki rozwój. Podstawy do obaw o załamanie gospodarcze regionu były uzasadnione, gdyż gospodarka w województwie katowickim, czyli w znacznej części Górnego Śląska, do połowy lat dziewięćdziesiątych XX wieku była nastawiona głównie na tzw. przemysł ciężki, czyli związany z górnictwem i hutnictwem. Zagrożenie to tym bardziej było prawdopodobne, gdyż w tym czasie załamały się gospodarczo rynki krajów Europy Środkowej i Wschodniej należące wcześniej wraz z Polską Rzeczpospolitą Ludową do grupy krajów nazywanych „demokracją ludową”, które do tego momentu były tradycyjnymi odbiorcami produktów wytwarzanych w Polsce. $\mathrm{W}$ takim okresie historycznym monostruktura gospodarcza regionu powodowała zrozumiałe obawy przed radykalnymi zmianami i utratą pracy przez znaczną część pracujących tu mieszkańców. Dlatego nowe władze państwowe oraz samorządowe po transformacji ustrojowej stanęły przed rewolucyjnymi wyzwaniami, jakimi była restrukturyzacja przemysłu.

Istniejący już od wielu lat w regionie przemysł motoryzacyjny stał się szansą dla rozwoju województwa. W poszukiwanie dróg wyjścia z trudnej sytuacji społeczno-gospodarczej mogli się włączyć nowi samorządowcy, którzy w liczbie ok. $80 \%$ zaczęli pełnić tę funkcję po raz pierwszy. Właściwa i przemyślana polityka regionalna miała tu więc szansę na dopasowanie się do możliwości gospodarczej ziemi śląskiej. Z pewnością przełomową sytuacją było tutaj opracowanie, w ramach istniejącego systemu prawnego, „Programu regionalnej polityki gospodarczej Górnego Śląska", który był realizowany od 1992 roku$^{6}$. Program ten był głównie kierowany do gmin i instytucji gospodarczych działających na terenie całego regionu. Zakładano, że głównym celem tego programu będzie

5 A.J. ScotT: New Industrial Space. Flexible Production Systems and Regional Development. The Rise of New Industrial Spaces in North America and Western Europe. "International Journal of Urban and Regional Research" June 1988; zob.: P. Dicken, M. ForsGreen, A. Malmberg: Local Embeddedness and Transnational Corporations. In: Globalization, Institutions and Regional Development in Europe. Eds. A. Amin, N. Thrift. Oxford 1994, s. $23-45$.

${ }^{6}$ Program regionalnej polityki gospodarczej Górnego Ślaska. Katowice 1995. 
przezwyciężenie załamania gospodarczego w całym województwie. Dokument ten jednak nie miał większych szans na wdrożenie, gdyż nie był skoordynowany z ogólnopolską strategią rozwoju gospodarczego i pobocznie zostały poruszone w nim sprawy restrukturyzacji przemysłu wydobywczego i metalurgicznego. Pomimo pewnych niespójności $\mathrm{w}$ tej koncepcji program stał się podstawą dla władz samorządowych do prac nad nowym projektem nazwanym „Kontraktem regionalnym dla województwa katowickiego"7. Decyzja o stworzeniu nowego dokumentu, gdzie tym razem zauważono potrzebę koniecznej koordynacji działań strony rządowej, tj. centrum decyzyjnego z samorządem regionalnym, spowodowała urealnienie potrzebnych reform na Górnym Śląsku. Została tutaj dostrzeżona konieczność restrukturyzacji przemysłu w regionie oraz potrzeba znalezienia nowych dróg rozwoju gospodarczego. Za następującym faktem, że aspekt gospodarczy zyskał na znaczeniu, przemawia to, że pomysł „Kontraktu regionalnego...” zrodził się w zespole Wydziału Gospodarki Urzędu Wojewódzkiego w Katowicach oraz w Górnośląskiej Agencji Rozwoju i Promocji S.A. (obecnie: Górnośląska Agencja Rozwoju Regionalnego S.A.).

Sprawy gospodarcze, które przebijają się na pierwszy plan, nie były jedynym celem tej umowy, jaką stanowił „Kontrakt regionalny...”. Ustalenia zawarte w tym dokumencie dotyczyły praktycznie wszystkich najważniejszych dziedzin życia społecznego w regionie, czyli ówczesnym województwie katowickim. Należy tu wymienić następujące działy, których ta umowa dotyczyła:

- edukacja;

- restrukturyzacja gospodarki;

— bezpieczeństwo socjalne;

- środowisko naturalne;

- opieka zdrowotna;

- transport i komunikacja;

— rozwój samorządności ${ }^{8}$.

Wszystkie te cele zostały tak skonstruowane, że wzajemnie się uzupełniały, co powodowało, że zwiększyła się szansa na powodzenie podjętej umowy. Wątek motoryzacyjny nie był praktycznie poruszany w „Kontrakcie regionalnym...”, ale nie ulega wątpliwości, że zawarte w nim postanowienia miały bezpośrednie przełożenie na rozwój tej branży. Tutaj należy przytoczyć spostrzeżenia i wyniki badań Bożeny Pietrzko, z których wynika jednoznacznie, że pod kątem hierarchii ważności celów w ramach tej umowy, jaką jest „Kontrakt regionalny...", restrukturyzacja całej gospodarki w regionie zajęła pierwsze miejsce i respondenci zaznaczyli tę odpowiedź w ponad połowie przypadków na

${ }^{7}$ Kontrakt regionalny dla województwa katowickiego. Katowice 1995.

${ }^{8}$ Szerzej: B. Pietrzko: Cele Kontraktu regionalnego... i ich hierarchia. W: Kontrakt regionalny dla województwa katowickiego. Dorobek i opinie. Red. M. BARAŃsKi. Katowice 1999, s. $15-29$. 
10 możliwych ${ }^{9}$. Następne dwa miejsca zajęły następujące odpowiedzi: ogólny wzrost gospodarczy oraz działania w kierunku ograniczenia bezrobocia. Autorka badań wyraźnie podkreśla, jaką rangę miał element gospodarczy w oczekiwaniach mieszkańców regionu, w tym okresie, kiedy powstawał projekt. W ramach restrukturyzacji gospodarczej zasadnicze cele to:

— wsparcie małej i średniej przedsiębiorczości;

- zmiana struktury własności oraz przebudowa zasad produkcji;

- wsparcie dla nowo powstających przedsięwzięć gospodarczych;

- podejmowanie kroków w celu ściągnięcia inwestorów zewnętrznych.

Na rozwój przedsiębiorczości, a co za tym idzie — rozwój przemysłu motoryzacyjnego, wpływ również miała i ma infrastruktura drogowa, kolejowa oraz transport lotniczy i rzeczny. Na terenie całego Górnego Śląska występuje najgęstsza sieć dróg w stosunku do innych regionów Polski. Podobnie wygląda sytuacja w odniesieniu do sieci kolejowej, gdyż ta w regionie jest również najgęstsza w porównaniu z resztą kraju. Transport lotniczy i wodny też miał i ma spore perspektywy w okręgu katowickim. „Kontrakt regionalny...” w okresie istnienia województwa katowickiego miał za zadanie umożliwić dalszą poprawę jakości komunikacji publicznej oraz wydajność transportu. Autorom projektu zależało również na rozbudowie dróg szybkiego ruchu, w tym autostrad, szybkiej kolei regionalnej i międzynarodowej oraz rozbudowie lotnisk, a także połączeń drogowych pomiędzy nimi. Również w ramach tych działań przewidywano przebudowę i rozbudowę sieci telekomunikacyjnej oraz wprowadzenie nowych technologii informatycznych.

Żeby osiągnąć tak znaczący efekt, konieczne było również dostosowanie, lub mówiąc bardziej precyzyjnie, dopasowanie całego systemu edukacji do potrzeb uczących się. $\mathrm{W}$ celu zrealizowania tego zamierzenia $\mathrm{w}$ umowie podkreślono następujący aspekt. Zwrócono uwagę na to, że należy dokonać zmiany struktury kształcenia, począwszy od zasadniczej szkoły zawodowej poprzez szkołę średnią po studia wyższe. W „Kontrakcie regionalnym...” mówi się także o potrzebie opracowania elastycznego systemu dokształcania i przekwalifikowywania osób już dorosłych, które zasadniczy okres edukacji mają za sobą. Zwrócono również uwagę na konieczność zwiększenia znaczenia środowiska akademickiego i naukowego w całym regionie. Oczekiwania także dotyczyły tego, że ta umowa wpłynie na powiększenie zaplecza materialnego w szkolnictwie wyższym oraz zwiększenie się liczby studentów. Uzupełnieniem tych propozycji był również plan opracowania systemu dodatkowej edukacji nauczycieli.

Wszystkie wymienione aspekty spowodowały, że „Kontrakt regionalny dla województwa katowickiego" stawał się w momencie jego powstawania wyjątkowo komplementarny i postępowy. Tak wielozakresowe podejście do problematyki regionu dawało szansę na jego zdecydowanie dynamiczny oraz najbardziej efek-

\footnotetext{
9 Ibidem.
} 
tywny rozwój. Mimo że województwo katowickie nie istnieje, a w jego miejsce utworzono większe województwo śląskie, które powstało z dniem 1 stycznia 1999 roku, w związku z reformą administracyjną kraju, to nadal program zawarty w tej umowie oddziałuje na cały region. Zwłaszcza że po powstaniu województwa śląskiego przekształcono tę umowę, urealniając jej zapisy do nowych warunków i nadając jej jednocześnie nazwę: Kontrakt Wojewódzki dla Województwa Śląskiego ${ }^{10}$. Ważne jest też to, że w kolejnych latach były ponawiane nowe Kontrakty Wojewódzkie... Miały one charakter umowy, tak jak w poprzednich latach, między samorządem województwa a rządem. Stworzone w nowej formie kontrakty określały zasady i zakres wspierania finansowego, które zostały zarysowane w kolejnych latach, w Programach Rozwoju Regionalnego Województwa.

W 2004 roku powstał Wojewódzki Program Operacyjny Województwa Śląskiego, który był następnie odnawiany w kolejnych latach. Zmiana nazwy i formuły wynikała bezpośrednio z przystąpienia Polski do Unii Europejskiej, co dokonało się 1 maja 2004 roku. Programy te miały przede wszystkim zapewnić zrównoważony rozwój społeczno-gospodarczy w regionie. Osiągnięcie tego zamierzenia miało być realizowane między innymi dzięki modernizacji oraz rozbudowie infrastruktury technicznej oraz poprzez wspieranie lokalnych inicjatyw gospodarczych i społecznych. Dużym ułatwieniem w przeprowadzaniu zmian stała się nowa możliwość, jaką było pozyskiwanie środków finansowych z Unii Europejskiej. Podstawę do tych działań stanowiła opracowana przez władze regionalne Strategia Rozwoju Województwa Śląskiego na lata 2000-2015, która była przyjęta we wrześniu 2000 roku. Kolejna aktualizacja tego dokumentu nastąpiła 4 lipca 2005 roku i łączyła się ze zmianą nazwy na Strategia Rozwoju Województwa Śląskiego na lata 2000-2020. Ostatnia aktualizacja tej wizji rozwoju miała miejsce w lutym 2010 roku, kiedy to przyjęto dokument pod nazwą Strategia Rozwoju Województwa Śląskiego „Śląskie 2020”. Strategie te są całkowicie kompletnymi dokumentami, które stały się podstawą do wyznaczania kierunków, w jakich ma zmierzać województwo śląskie i przed jakimi zagrożeniami ma się bronić. Jak już zostało wcześniej przedstawione, Strategia Rozwoju Województwa Śląskiego... była podstawą do utworzenia Kontraktów Wojewódzkich... i Wojewódzkich Programów Operacyjnych Województwa Śląskiego...

Wymienione dokumenty miały i nadal mają ogromne znaczenie dla spraw gospodarczych, co jednocześnie przekłada się na aspekt przemysłu motoryzacyjnego $\mathrm{w}$ województwie śląskim. Wielu obserwatorów działań gospodarczych w województwie śląskim zauważa, że w sposób zdecydowany wszystkie te działania polityczne wpływają na procesy restrukturyzacyjne regionu. W gospodarce zmniejsza się zdecydowanie udział górnictwa i hutnictwa, branż do niedaw-

${ }^{10}$ Kontrakt Wojewódzki dla Województwa Śląskiego — http://www.slaskie.pl/plstrona_n. php?jezyk=pl\&grupa=3\&dzi=1248435846\&id_menu=69 (dostęp: 28.01.2014). 
na dominujących w całej strukturze przemysłowej województwa. Jednocześnie wyraźnie wzrasta pozycja przemysłu energetycznego, informatycznego, elektromaszynowego i najszybciej rozwijających się dwóch branż — spożywczej oraz motoryzacyjnej ${ }^{11}$. Tak jak już było wcześniej prezentowane, doskonałe położenie geograficzne województwa śląskiego, zaplecze naukowe, techniczne, dostęp do naturalnych zasobów oraz również wysoka kultura pracy wśród mieszkańców w połączeniu z koncepcjami władz regionalnych spowodowały wysoką pozycję inwestycyjną tego regionu.

Utrzymanie w województwie fabryki Fiata oraz wybudowanie całkowicie nowego zakładu Opla, tj. przedsiębiorstw, które są producentami samochodów, oraz powstanie również nowego zakładu produkującego silniki wysokoprężne japońskiej firmy Isuzu spowodowało dalszy wzrost atrakcyjności regionu, a co za tym idzie - powstanie kolejnych zakładów kooperujących — zarówno z kraju, jak i z zagranicy. Województwo ma dzięki tym przedsięwzięciom największy udział w skali kraju w zakresie produkcji samochodów osobowych oraz stali surowej, a to również wzmacnia jego atrakcyjność inwestycyjną ${ }^{12}$. Doskonale uwidacznia tę sytuację wykres 1 .

Prezentowany wykres 1 wyraźnie obrazuje wzrost znaczącej roli branży motoryzacyjnej wraz z jednoczesnym osłabieniem pozycji przemysłu potocznie nazywanego ciężkim. Mimo to bliskie zaplecze kopalń i hut jest pewnym wsparciem dla branży motoryzacyjnej pod względem dostarczania podstawowych elementów stalowych. Jednak rozwijająca się branża samochodowa daje również szanse dla kooperantów, producentów produktów wysoce przetworzonych, w tym producentów zdecydowanie rozwiniętych technologicznie, na zwiększanie produkcji i wzrost zatrudnienia. Fabryka Opla w Gliwicach oraz zakład silników Isuzu zostały wybudowane na terenie Katowickiej Strefy Ekonomicznej. Przez ponad dwadzieścia lat w tej strefie zainwestowało ok. 100 przedsiębiorców i ta wartość ciągle rośnie. Przyczyniło się to do zaimplementowania nowoczesnych technologii, a także dało szansę do zatrudnienia kilkudziesięciu tysięcy pracowników. Były minister przemysłu i handlu, Klemens Ścierski, chcąc podkreślić rosnącą rolę motoryzacji w województwie śląskim, stwierdził, że podstawą tego sukcesu stała się Katowicka Specjalna Strefa Ekonomiczna ${ }^{13}$. Przykład ten wyraźnie ukazuje, że pomimo obiektywnie sprzyjających warunków do inwestowania w regionie ciągle są potrzebne rozmaite działania, które dalej będą pobudzać drzemiący w tym województwie potencjał, co właśnie czyni Specjalna Strefa Ekonomiczna.

11 Ibidem.

12 Instytut BAdAŃ NAD Gospodarką Rynkową: Atrakcyjność inwestycyjna województw i podregionów Polski 2008. Red. T. KALINowski. Gdańsk 2008.

1310 przemysłowych naj $w$ woj. ślaskim. Mocno stoimy motoryzacja $i$ lotnictwem http://www.dziennikzachodni.pl/artykul/396682,10-przemyslowych-naj-w-woj-slaskim-moc no-stoimy-motoryzacja-i-lotnictwem,id,t.html (dostęp: 28.01.2014). 


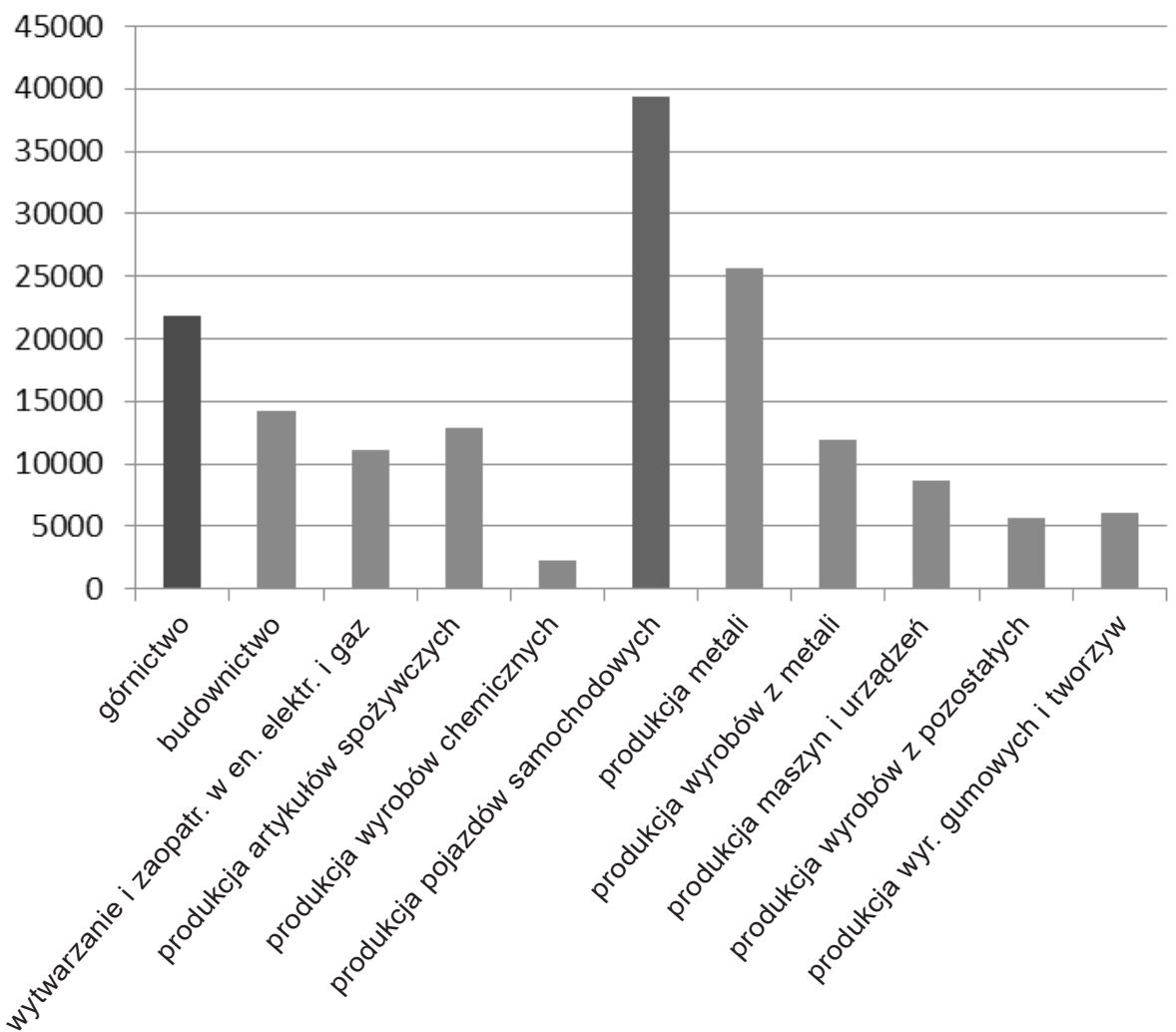

Wykres 1. Udział różnych branż w przemyśle województwa śląskiego. Przemysł 163 840,5 (mln zl)

Źródło: Opracowanie własne na podstawie materiałów Urzędu Statystycznego w Katowicach, Śląskie w liczbach 2009.

Nie ulega wątpliwości, że funkcjonowanie w dzisiejszej wysoce konkurencyjnej gospodarce wymusza na przedsiębiorstwach konieczność dopasowania się do ewoluujących warunków prowadzenia działalności produkcyjnej i usługowej. Zarządzający przedsiębiorstwami zdają sobie sprawę z tego, że zbyt wolne reagowanie na postępujący rozwój technologiczny może stać się przyczyną podupadania przedsiębiorstw lub nawet znikania ich z rynku' ${ }^{14}$. Zarządzający współczesnymi przedsiębiorstwami, a co za tym idzie - również branżą motoryzacyjną - zdają sobie doskonale sprawę z tego, iż doprowadzenie do wysokiego poziomu efektywności można osiągnąć, wprowadzając innowacyjność. Województwo śląskie, a w ramach niego Katowicka Specjalna Strefa Ekonomiczna, daje takie możliwości, żeby zdobyć przewagę technologiczną. Bezsprzeczne

14 P.F. Drucker: Innowacja i przedsiębiorczość. Praktyka i zasady. Przeł. A. EHrLich. Warszawa 1992, s. 162. 
jest, że firmy, które jednak funkcjonują w otoczeniu pozbawionym specjalnych preferencji, mogą mieć utrudnioną drogę do wprowadzania innowacyjności, a co za tym idzie - właściwego poziomu efektywności. Osiągnięcie przewagi konkurencyjnej jest możliwe jedynie dzięki wdrażaniu technologii najbardziej nowatorskich i jednocześnie tak zabezpieczonych, żeby były trudne do skopiowania. Jak wskazuje wielu obserwatorów i badaczy sfery przedsiębiorstw w województwie śląskim, czyli w specyficznych warunkach regionu mocno uprzemysłowionego, produkcja pojazdów samochodowych, przyczep i naczep należy do najbardziej nowatorskich i innowacyjnych ${ }^{15}$.

Kolejnym, szczególnie ważnym elementem, sprzyjającym rozwojowi przemysłu motoryzacyjnego, jest otoczenie biznesu. Na terenie całego województwa śląskiego jest blisko 200 instytucji takiego typu. Są to różnego rodzaju izby przemysłowe, gospodarcze, handlowe, cechy rzemieślnicze, instytucje wspierające przedsiębiorczość, stowarzyszenia gospodarcze oraz agencje rozwoju regionalnego. Także tu okazuje się, że Górny Śląsk jest liderem w liczbie działających i nowo powstających parków technologicznych i przemysłowych. Do najważniejszych instytucji wspierających i reprezentujących przedsiębiorców należą:

— Izba Rzemieślnicza oraz Izba Małej i Średniej Przedsiębiorczości w Katowicach;

- Regionalna Izba Gospodarcza;

- Górnicza Izba Przemysłowo-Handlowa;

- Hutnicza Izba Przemysłowo-Handlowa;

- Górnośląska Agencja Rozwoju Regionalnego;

- Górnośląska Agencja Promocji Przedsiębiorczości;

- Fundusz Górnośląski ${ }^{16}$.

Działania polityczne władz samorządowych dzisiejszego województwa śląskiego oraz władz centralnych Rzeczypospolitej Polskiej, których efektem było powstanie „Kontraktu regionalnego...”, Kontraktu Wojewódzkiego... i Strategii Rozwoju Województwa Śląskiego... miały na celu, jak już wspomniano wcześniej, rozwój ekonomiczny, całościowe wsparcie społeczności lokalnej oraz większą pomoc ze strony samorządowej dla prowadzących działalność i rozpoczynających działalność gospodarczą. W ramach tych priorytetów okazało się, że wskazane było powołanie Katowickiej Specjalnej Strefy Ekonomicznej. Miał to być istotny instrument wspierający regionalny rozwój gospodarczy. Tego typu oczekiwania zostały już wyraźnie wyartykułowane w rozdziale V „Kontraktu regionalnego..." zatytułowanym Gospodarka.

${ }_{15}$ M. Pichlak: Uwarunkowania innowacyjności przedsiębiorstw $w$ regionie przemystowym - na przykładzie województwa śląskiego. Katowice 2011, s. 68-74.

16 J. PAjąK: Możliwości produkcyjne i inwestycyjne województwa śląskiego. Bielsko-Biała 2011, s. 6-10 — https://docplayer.pl/14599550-Autor-jan-pajak-bielsko-biala-2011-sto warzyszenie-osrodek-wspierania-turystyki-przedsiebiorczosci-i-rozwoju-lokalnego.html (dostęp: 13.04.2014). 
Podstawą prawną specjalnych stref ekonomicznych w kraju stała się ustawa uchwalona w październiku 1994 roku $^{17}$. Z jej mocy oraz na mocy przyjętego rozporządzenia Rady Ministrów z 8 czerwca 1996 roku została ustanowiona w województwie katowickim Katowicka Specjalna Strefa Ekonomiczna (KSSE) na okres dwudziestu lat ${ }^{18}$. Specjalne strefy ekonomiczne mają za zadanie umożliwianie tworzenia nowych miejsc pracy, stwarzanie szans dla polskich przedsiębiorców oraz przyciąganie kapitału uznanych firm zagranicznych. Organizacja działalności w takich strefach jest regulowana na specjalnych preferencyjnych zasadach. Przede wszystkim kwestia ta dotyczy aspektów podatkowych. Znaczącą korzyścią jest również specjalnie przygotowany i uzbrojony teren w Katowickiej Specjalnej Strefie Ekonomicznej. KSSE jest zlokalizowana na obszarze 8 gmin i w jej skład wchodzą 4 podstrefy:

1) gliwicka;

2) sosnowiecko-dąbrowska;

3) jastrzębsko-żorska;

4) tyska.

Od 30 czerwca 2018 roku w związku z intensywnymi działaniami rządu i przyjęciem przez sejm ustawy z 10 maja 2018 roku o wspieraniu nowych inwestycji, terytorium całej Rzeczypospolitej Polskiej zaczęło spełniać warunki Specjalnej Strefy Ekonomicznej. Pomimo to wszyscy przedsiębiorcy działający na dotychczasowych zasadach w SSE będą mogli funkcjonować do 2026 roku, czyli do zakończenia działalności specjalnych stref ekonomicznych. Będzie również możliwość wydłużenia czasu obowiązywania decyzji aż do piętnastu lat, w przypadku wszystkich terenów objętych obecnie statusem SSE.

Wszelkie przedsięwzięcia realizowane w regionie w ramach „Kontraktu regionalnego dla województwa katowickiego" czy też Kontraktu Wojewódzkiego dla Województwa Śląskiego w ramach Strategii Rozwoju Województwa Śląskiego... potrzebowały ludzi wykształconych o nowoczesnym podejściu do czekających ich wyzwań w regionie. Dlatego też, mimo że już częściowo zostały poruszone kwestie związane z edukacją, to jeszcze należy o tym aspekcie przedstawić kilka informacji. O znaczeniu szeroko pojętej nauki w województwie w odniesieniu do restrukturyzacji tegoż województwa może świadczyć fakt, że w Kontrakcie regionalnym... rozdział I zatytułowano Edukacja. W tym rozdziale mówi się między innymi o tym, że powinno się stworzyć regionalny system edukacji oparty na znowelizowanych przepisach regulujących zasady tworzenia szkół i placówek nowego typu oraz wprowadzić zupełnie nowe kierunki kształcenia, w których uwzględniano by potrzeby rynku pracy w regionie ${ }^{19}$.

${ }_{17}$ Ustawa z 20 października 1994 r. o specjalnych strefach ekonomicznych (Dz.U. 1994 r., Nr 123, poz. 600 i z 1996 r., Nr 106, poz. 496).

18 Rozporządzenie Rady Ministrów z 8 czerwca 1996 r. w sprawie ustanowienia specjalnej strefy ekonomicznej w województwie katowickim (Dz.U. z 1996 r., Nr 88, poz. 397 i Dz.U. z 1997 r. Nr 28, poz. 155).

${ }^{19}$ Kontrakt regionalny..., s. 4-6. 
Na szczególną uwagę zasługuje edukacja związana z kształceniem na uczelniach wyższych $\mathrm{w}$ regionie. Oferta $\mathrm{w}$ tym zakresie jest bardzo szeroka, gdyż studenci mają do wyboru znaczną liczbę uczelni publicznych i niepublicznych na obszarze całego województwa śląskiego. Ulokowanie uczelni wyższych w obszarze całego województwa można zaprezentować w ramach co najmniej pięciu subregionów. Tymi subregionami są: katowicki, gliwicki, sosnowiecki, częstochowski i bielski. Największa oferta edukacyjna dotyczy subregionów katowickiego i gliwickiego, gdzie łącznie w skali całego województwa jest ponad $60 \%$ miejsc dla studiujących. W subregionie katowickim kształci się najczęściej studentów: administracji, nauk prawnych, ekonomii, nauk społecznych, biologicznych, medycznych, informatycznych oraz usług dla ludności. Z kolei w subregionie gliwickim najliczniejszą grupę stanowią absolwenci nauk inżynieryjno-technicznych, architektury i budownictwa, usług transportowych oraz ochrony środowiska ${ }^{20}$. Tak dobre zlokalizowanie ośrodków naukowych ma też znaczący wpływ na powstanie dużej liczby instytutów badawczo-rozwojowych w zakresie przemysłu samochodowego w województwie śląskim. Można tutaj wymienić następujące jednostki naukowe, wspierające sektor motoryzacji, które funkcjonują na terenie województwa śląskiego:

- Instytut Metalurgii Żelaza;

- Instytut Metali Nieżelaznych;

- Instytut Spawalnictwa;

- Politechnika Śląska;

- Politechnika Częstochowska;

- Akademia Techniczno-Humanistyczna w Bielsku Białej;

- Instytut Badań i Rozwoju Motoryzacji BOSMAL sp. z o.o.;

- Centrum Materiałów Polimerowych i Węglowych PAN ${ }^{21}$.

Tylko częściowe zasygnalizowanie kwestii edukacyjnych wyraźnie pokazuje, że zwiększanie oferty edukacyjnej na każdym poziomie kształcenia jest niezmiernie ważne i w sposób oczywisty sprzyja rozwojowi gospodarczemu województwa. Zasługą władz województwa jest to, że zauważyły tę potrzebę i że ta kwestia pojawiła się też w programach, i dokumentach regulujących rozwój województwa.

Na szczególną pozycję i rozwój przemysłu motoryzacyjnego w województwie śląskim miało i ma wpływ wiele czynników. Decyzje polityczno-gospodarcze władz samorządowych województwa śląskiego, a wcześniej katowickiego, miały z pewnością duże znaczenie dla rozwoju branży motoryzacyjnej w regionie. „Kontrakt dla województwa katowickiego”, Kontrakt Wojewódzki dla Województwa Śląskiego, Strategia Rozwoju Województwa Śląskiego oraz Wo-

20 J. PająK: Możliwości produkcyjne..., s. 10-12.

${ }_{21}$ M. Baron, L. Palmen, M. Chojkowski, P. Soltysik: Obszary wspótpracy sfery nauki i przedsiębiorstw $w$ sektorze motoryzacyjnym $w$ województwie śląskim. W: Uwarunkowania wspótpracy nauki i biznesu w sektorze motoryzacyjnym w województwie. Red. R. OpRYCH. Katowice 2011, s. 12-13. 
jewódzki Program Operacyjny Województwa Śląskiego, a także wiele innych umów i decyzji stały się podstawą do rozbudowy i unowocześnienia przemysłu motoryzacyjnego w dzisiejszym województwie śląskim. Duże znaczenie ma tutaj również istniejący już od kilku stuleci potencjał przemysłowy regionu, znacząca i liczna kadra inżynieryjno-techniczna, dobre techniczne wykształcenie pracowników każdego szczebla, rozwinięte szkolnictwo na każdym poziomie edukacyjnym, zaplecze naukowo-badawcze, a także znacząca użyteczność instytucji wspierających. Wszystko to sprawia, że województwo śląskie ma silną pozycję gospodarczą, zachęcającą do dalszego inwestowania przedstawicieli zagranicznych i krajowych firm. Stwarza to wyjątkową szansę na przejście od przemysłu, który przeważał regionie od wielu stuleci i był związany z wydobyciem węgla kamiennego oraz wytopem stali, do produkcji urządzeń wysoko przetworzonych, jakimi są z pewnością pojazdy samochodowe. Takie podejście staje się tym bardziej ważne, gdyż, jak pokazuje doświadczenie innych rozwiniętych gospodarek, znaczący rozwój gospodarczy można osiągnąć, stawiając na produkcję zaawansowaną technologicznie, wspieraną przez rodzime zaplecze naukowo-badawcze. Możliwości, jakie do tej pory zostały stworzone poprzez właściwe działania polityczne, nie mogą zostać zaprzepaszczone i nadal władze centralne państwa polskiego, a także elity polityczne województwa śląskiego powinny pracować nad wspieraniem rozwoju przemysłu motoryzacyjnego w tym regionie. Szczególnie może być to ważne w sytuacji, kiedy uzmysłowimy sobie twierdzenie, iż branża motoryzacyjna nadal będzie należała do bardzo rozwojowych i perspektywicznych, co z pewnością bezpośrednio wpłynie na dynamiczny rozwój województwa. Nie osłabi tego, a wręcz nawet wzmocni, nowy rządowy plan elektromobilności w naszym kraju na najbliższe lata.

\section{Bibliografia}

10 przemystowych naj $w$ woj. śląskim. Mocno stoimy motoryzacja i lotnictwem http://www.dziennikzachodni.pl/artykul/396682,10-przemyslowych-naj-w-wojslaskim-mocno-stoimy-motoryzacja-i-lotnictwem,id,t.html (dostęp: 28.01.2014).

Baron M., Palmen L., Chojkowski M., Soltysik P.: Obszary wspótpracy sfery nauki i przedsiębiorstw $w$ sektorze motoryzacyjnym $w$ województwie ślaskim. W: Uwarunkowania wspótpracy nauki i biznesu $w$ sektorze motoryzacyjnym w województwie. Red. R. OPRYCH. Katowice 2011.

Dicken P., Forsgreen M., Malmberg A.: Local Embeddedness and Transnational Corporations. In: Globalization, Institutions and Regional Development in Europe. Eds. A. Amin, N. Thrift. Oxford 1994.

Drucker P.F.: Innowacja i przedsiębiorczość. Praktyka i zasady. Przeł. A. EHRLich. Warszawa 1992. 
Instytut BADAŃ NAD Gospodarką Rynkową: Atrakcyjność inwestycyjna województw i podregionów Polski 2008. Red. T. KaLINOwSKI. Gdańsk 2008.

Jarosz A., LeŚniak-Moczuk K.: Polityka regionalna. Rzeszów 1998.

Kontrakt regionalny dla województwa katowickiego. Katowice 1995.

Kontrakt Wojewódzki dla Województwa Śląkiego — http://www.slaskie.pl/pl strona_n.php?jezyk=pl\&grupa $=3 \& d z i=1248435846 \& i d \_m e n u=69$ (dostęp: 28.01 . 2014).

PAJĄK J.: Możliwości produkcyjne i inwestycyjne województwa śląskiego, Bielsko-Biała 2011 — https://docplayer.pl/14599550-Autor-jan-pajak-bielsko-biala-2011stowarzyszenie-osrodek-wspierania-turystyki-przedsiebiorczosci-i-rozwoju-lo kalnego.html (dostęp: 13.04.2014).

PICHLAK M.: Uwarunkowania innowacyjności przedsiębiorstw $w$ regionie przemysłowym - na przykładzie województwa ślaskiego. Katowice 2011.

Pietrzko B.: Cele Kontraktu regionalnego... i ich hierarchia. W: Kontrakt regionalny dla województwa katowickiego. Dorobek i opinie. Red. M. BARAŃsKI. Katowice 1999.

Program regionalnej polityki gospodarczej Górnego Śląska. Katowice 1995.

Rozporządzenie Rady Ministrów z 8 czerwca 1996 r. w sprawie ustanowienia specjalnej strefy ekonomicznej w województwie katowickim. (Dz.U. z 1996 r. Nr 88, poz. 397 i Dz.U. z 1997 r., Nr 28, poz. 155).

Scotт A.J.: New Industrial Space. Flexible Production Systems and Regional Development: the Rise of New Industrial Spaces in North America and Western Europe. "International Journal of Urban and Regional Research" June 1988.

Siemianowicz J.: Czynniki produkcji przemystowej i eksport makroregionu poludniowego $w$ procesie transformacji gospodarki. Kraków-Katowice-Zabrze 2001.

Szelichowski S.: Dzieje polskiej motoryzacji. Łódź 2012.

Ślaskie — nowoczesny przemyst motoryzacyjny — http://www.slaskie.pl/strona_n. php?jezyk=pl\&grupa=10\&art=5122 (dostęp: 7.01.2014).

Ustawa z 20 października 1994 r. o specjalnych strefach ekonomicznych (Dz.U. z 1994 r., Nr 123, poz. 600 i z 1996 r. Nr 106, poz. 496).

Krzysztof Toboła, mgr, politolog oraz technik mechanik o specjalności „naprawa i eksploatacja pojazdów samochodowych”, a także mistrz o specjalności „mechanik pojazdów samochodowych". Ukończył studia doktoranckie na Wydziale Nauk Społecznych Uniwersytetu Śląskiego w Katowicach. Zainteresowania: przemiany ustrojowe w Polsce oraz w całym regionie Europy Środkowo-Wschodniej z przełomu lat osiemdziesiątych i dziewięćdziesiątych XX wieku. Zakres tematyczny rozprawy doktorskiej: „Wpływu polityki państwa na zachowania konsumenckie, na przykładzie polskiego przemysłu motoryzacyjnego". 